\title{
BIODIVERSITY OF THE BUNDALA NATIONAL PARK AND RAMSAR WETLAND
}

\author{
CNB Bambaradeniya, SP Ekanayake, RHSS Fernando, R Somaweera and \\ N Perera \\ IUCN - The World Conservation Union, Horton Place, Colombo 07
}

The Bundala National Park (6216 ha) is located in the Hambantota District, within the Southeastern Arid Zone of Sri Lanka. The park consists mainly of dry thorny scrubland and lagoons; Koholankala (390 ha), Malala (65t ha), Embilikala (430 ha) and Bundala (520 ha). These shallow water lagoons form a complex wetland system that harbours a rich bird life, including several species of migratory wateriowl. Bundala is Sri Lanka's first Ramsar wetland-a wetland of international importance especially for migratory waterfowl. Recent studies have indicated that the Bundala National Park and its wetlands are being degraded by various adverse factors. Therefore, this survey was inten $l \mathrm{~d} d$ to document the present status of biodiversity in this protected area, and the threats it faces today. The systematic survey on biodiversity extended from January to April 2001, during which the area was visited at fortnightly intervals. The fauna and flora were surveyed using scientifically valid inventorying techniques. The survey enabled to document 7 major terrestrial vege ation/habitat types (dry thorny scrubland, Arid zone forests, sand dune vegetation, gentle sea shore vegetation, Arid zone maritime grasslands/pastures, Riverine forest, anomalous Mesquite (Prosopis) scrublands and 6 wetland types (saltmarsh, mangrove, brackish water lagoons, sandy and rocky sea shore, seasonal water holes and tanks, saltern ) in Bundala. A total of 383 plant species have been documented from the above vegetation and habitat types in Hundala. These include 6 endemics and 7 species that are considered as nationally threatened. Shrubs and herbs (plants with leaves and non-woody stems) are the predominant plant life forms of Bundala. A total of 324 species of vertebrates have been recorded from Bundala National Irark, of which 11 species are endemic, while 29 species are nationally threatened. Among the invertebrates are 52 species of colourful butterflies.

At present, the biodiversity of Buncala National Park is facing several threats, which could be summarised under habitat deterior ation and degradation (i.e., Shell mining, driving of vehicles off the recommended tracks, discharge of irrigation water in to lagoons, release of sludge into the Bundala lagoon), direct exploitation of species (poaching, felling of trees, road kills), spread of invasive alien species (4 animal species and 15 plant species), prolonged drought, and unplanned land-use practices. It is envisaged that these findings would contribute to the conservation and management of this globally important PA. 